\title{
Study on inclusion of probiotic, prebiotic and its combination in broiler diet and their effect on carcass characteristics and economics of commercial broilers
}

\author{
M. A. Saiyed ${ }^{1}$, R. S. Joshi², F. P. Savaliya ${ }^{3}$, A. B. Patel ${ }^{3}$, R. K. Mishra ${ }^{3}$ and N. J. Bhagora ${ }^{3}$
}

\begin{abstract}
1. Veterinary Dispensary Tarapur, District Panchayat Anand, Gujarat, India; 2. Department of Animal Genetics \& Breeding, Veterinary College, Anand Agricultural University, Anand, Gujarat, India; 3. Poultry Complex, Veterinary College, Anand Agricultural University, Anand, Gujarat, India.
\end{abstract}

Corresponding author: M. A. Saiyed, email: dr.shahid92@gmail.com, RSJ: rsjoshi106@gmail.com, FPS: fpsavaliya@yahoo.com, ABP: patelab1411@yahoo.co.in, RKM: rkmishra@gmail.com, NJB: nikeshbhagora@ymail.com Received: 09-12-2014, Revised: 03-01-2015, Accepted: 09-01-2015, Published online: 25-02-2015

doi: 10.14202/vetworld.2015.225-231. How to cite this article: Saiyed MA, Joshi RS, Savaliya FP, Patel AB, Mishra RK, Bhagora NJ (2015) Study on inclusion of probiotic, prebiotic and its combination in broiler diet and their effect on carcass characteristics and economics of commercial broilers, Veterinary World 8(2):225-231.

\begin{abstract}
Background and Aim: In today era, broiler industry facing a problem of price hiking of feed of broiler, also in competitive era there should be lower feed cost, lower feed conversion ratio, low feed consumption yet good body weight at marketable age.

Materials and Methods: Day-old commercial broiler chicks $(n=200)$ were distributed randomly into 5 dietary treatment groups viz. control $\left(\mathrm{T}_{1}\right)$, probiotic in the feed @ $100 \mathrm{~g} /$ tonne of feed $\left(\mathrm{T}_{2}\right)$, prebiotic in the feed @ $500 \mathrm{~g} /$ tonne of feed $\left(\mathrm{T}_{3}\right)$, probiotic + prebiotic@100 g/tonne and $500 \mathrm{~g} /$ tonne of feed, respectively $\left(\mathrm{T}_{4}\right)$ and probiotic + prebiotic @ $50 \mathrm{~g} /$ tonne and $250 \mathrm{~g} /$ tonne of feed $\left(\mathrm{T}_{5}\right)$. The growth of broilers and dressing weight along with the weight of giblet (liver without gall bladder, gizzard without serous layer, and heart without pericardium), Kidney, Abdominal fat, Length of Intestine and dressing percentage were measured. Economics in terms of Return Over Feed Cost (ROFC) and European Performance Efficiency Index (EPEI) was calculated.
\end{abstract}

Results: Among all carcass traits, dressing percentage, abdominal fat weight and abdominal fat percentage (as a percentage of dressed weight) were recorded significant $(\mathrm{p}<0.05)$ difference among different treatment groups. The income from selling of the birds was significantly $(\mathrm{p}<0.05)$ higher in all treatment groups than the control group but there was a non-significant difference between supplemented groups. Feed cost during whole experimental period was significantly $(\mathrm{p}<0.05)$ lower in synbiotic supplemented groups $\left(\mathrm{T}_{4}\right.$ and $\left.\mathrm{T}_{5}\right)$ than other groups. ROFC of all treatment group found significantly $(\mathrm{p}<0.05)$ higher than the control group.

Conclusion: It can be concluded that the diet supplemented with synbiotic (100\% level) was most efficient in terms of EPEI and synbiotic ( $50 \%$ level) in terms of ROFC. Hence, as feed supplement, synbiotic has a beneficial effect over probiotic and prebiotic when used alone.

Keywords: broiler, carcass traits, European Performance Efficiency Index, prebiotic, probiotic, Return Over Feed Cost, symbiotic.

\section{Introduction}

Poultry is one of the fastest growing segments among the component of livestock sector in India. Production of agricultural crops has been growing at a rate of $1.5-2.0 \%$ per annum while poultry industry is growing at $8-15 \%$ per annum in India. The organized sector of the poultry is contributing nearly $70 \%$ of the total output and the rest $30 \%$ by the unorganized sector. About $66.7 \%$ of the total output from poultry is realized from the poultry meat sector and only $33.3 \%$ from egg production. The total poultry population, which was only 73.5 million in 1951 has made tremendous growth during the past 50 years and has reached 648.83 million as per 2007 Census. India occupied the $3^{\text {rd }}$ position in egg production and $5^{\text {th }}$ position in poultry meat production as per 2010 census in the

Copyright: The authors. This article is an open access article licensed under the terms of the Creative Commons Attributin License (http:// creative commons.org/licenses/by/2.0) which permits unrestricted use, distribution and reproduction in any medium, provided the work is properly cited. world. The per capita availability of poultry meat is $2.15 \mathrm{~kg} /$ annum, which is very less as against the recommendation of $11 \mathrm{~kg}$ meat/annum given by National Institute of Nutrition [1].

Feed as a major input item to broiler rearing for being $75 \%$ of the production cost has a vital role in broiler economics. Hence, it is imperative to give due attention to proper utilization of feed without adversely affecting the growth or production performance of broilers [2]. Antibiotics have been also used to promote growth rate, improve feed conversion ratio (FCR) and reduce mortality in broiler flocks. However, repeated use of antibiotics in poultry diets resulted in severe problems like resistance of pathogen to antibiotics, accumulation of antibiotics residue in their products and environment, imbalance of normal microflora and reduction in beneficial intestinal microflora $[3,4]$.

This has led to the development of different products to be used as feed additives such as enzymes, probiotics, prebiotics, organic acids, and plant extracts. Probiotics are "live microorganisms, which when 
administered in adequate amounts confer a health benefit on the host" [5]. Whereas prebiotics are defined as non-digestible food ingredients that beneficially affect the host by selectively stimulating the growth and activity of one or a limited number of bacteria. Synbiotics refer to nutritional supplements combining probiotics and prebiotics and in a form of synergism. The main reason, for using a synbiotic, is that a true probiotic, without its prebiotic food, does not survive well in the digestive system. Without the necessary food source for the probiotic, it will have a greater intolerance for oxygen, low $\mathrm{pH}$, and temperature [6]. Poultry meat production has been paid more and more attention because it is particularly high in quantities and qualities of valuable protein, essential amino acids, fat, essential fatty acids, vitamins and minerals. Poultry meat is a high quality concentrated food and, therefore, plays an important role in human nutrition [7]. Poultry meat constitutes around $20 \%$ of total meat production in the country [8].

\section{Materials and Methods}

\section{Ethical approval}

The present study was carried out at the age of 42 days/ 6 week and carcass parameters were carried out at chicken shop with due care after selling of the birds.

\section{Experimental design}

A 200-day-old commercial broiler chicks were randomly distributed into five different treatment groups having four replicates in each treatment with 10 chicks in each replicate and they were reared under battery brooder system of cage up to 42 days of age.

\section{Experimental procedure}

Feed and water were offered ad libitum, and standard managemental practices followed. Chicks were weighed individually at the start of the experiment and at the end of every week. Mortality was also recorded. Composition of dietary treatments is given in Table-1. Proportion of different feed ingredient is shown in Table- 2 and detailed composition of feed additives is shown in Table-2.1 First group of birds were kept as a control, and they were not supplied feed with either probiotic or prebiotic in both, broiler starter and broiler finisher feed. Probiotic in the feed of $\mathrm{T}_{2}$ group was given at the rate of $100 \mathrm{~g} /$ tonne of feed during the starter phase (0-4 weeks) and finisher

Table-1: Composition of dietary treatment employed.

\begin{tabular}{ll}
\hline $\begin{array}{l}\text { Dietary } \\
\text { treatment }\end{array}$ & Composition \\
\hline $\mathrm{T}_{1}$ & Basal diet without additive, served as control \\
$\mathrm{T}_{2}$ & Basal diet+Probiotic @ $100 \mathrm{~g} /$ tonne of feed \\
$\mathrm{T}_{3}$ & Basal diet+Prebiotic @ $500 \mathrm{~g} /$ tonne of feed \\
$\mathrm{T}_{4}$ & Basal diet+Probiotic @ $100 \mathrm{~g} /$ tonne of \\
& feed+Prebiotic @ $500 \mathrm{~g} / \mathrm{tonne}$ of feed \\
$\mathrm{T}_{5}$ & Basal diet+Probiotic @ $50 \mathrm{~g} /$ tonne of \\
& feed+Prebiotic @ $250 \mathrm{~g} /$ tonne of feed \\
\hline
\end{tabular}

phase (5-6 weeks). Prebiotic in the feed of $\mathrm{T}_{3}$ group was given at the rate of $500 \mathrm{~g} /$ tonne of feed during the starter phase and finisher phase. In $\mathrm{T}_{4}$ group, probiotic was given at the rate of $100 \mathrm{~g} /$ tonne of feed and Prebiotic was given at the rate of $500 \mathrm{~g} /$ tonne of feed during the starter phase and finisher phase.

Table-2: Proportion of feed ingredients (\%) used for preparation of broiler starter and finisher feeds.

\begin{tabular}{|c|c|c|}
\hline \multirow[t]{2}{*}{ Ingredients } & \multicolumn{2}{|c|}{ Proportion (Kg) } \\
\hline & $\begin{array}{l}\text { Broiler } \\
\text { starter }\end{array}$ & $\begin{array}{l}\text { Broiler } \\
\text { finisher }\end{array}$ \\
\hline Maize & 53.900 & 54.075 \\
\hline Deoiled rice bran & 1.150 & 9.150 \\
\hline Soyabean DOC & 39.755 & 30.500 \\
\hline Trace mineral $^{1}$ & 0.100 & 0.000 \\
\hline Shell grit & 2.200 & 1.700 \\
\hline $\mathrm{DCP}$ & 2.000 & 1.390 \\
\hline Salt & 0.300 & 0.400 \\
\hline Enzymes ${ }^{2}$ & 0.050 & 0.050 \\
\hline Furazolidone $^{3}$ & 0.025 & 0.050 \\
\hline Metabolic activator ${ }^{4}$ & 0.100 & 0.100 \\
\hline Toxin binder 5 & 0.100 & 0.100 \\
\hline Maduramicin 6 & 0.050 & 0.050 \\
\hline Lysine & 0.100 & 0.100 \\
\hline DLMethionine & 0.135 & 0.090 \\
\hline Herbal performance enhancer ${ }^{7}$ & 0.025 & 0.025 \\
\hline Vitamin $\mathrm{B}_{12}^{8}$ & 0.010 & 0.020 \\
\hline Vegetable oil & 0.000 & 2.000 \\
\hline Vitamin and mineral supplement ${ }^{9}$ & 0.000 & 0.200 \\
\hline Total & 100.00 & 100.00 \\
\hline CP $(\%) *$ & 23.10 & 20.20 \\
\hline ME (kcal/kg feed)* & 2800.00 & 2900.00 \\
\hline
\end{tabular}

*As per calculated values, $\mathrm{DCP}=$ Digestible crude protein

Table-2.1: Detailed composition of feed additives added in feed.

\section{Trace Minerals:}

Each kg contains:

Copper-15 g, Iodine-1 g, Iron-60 g, Manganese-80 g, Selenium-0.3 g, Zinc-80 g, Inorganic nutritive care-Q.S.

2. Enzymes:

Each gram contains:

Xylanase-2000 IU, Amylase-400 IU, Protease-4000 IU, Cellulase-500 IU.

3. Furazolidone:

Each kg contains:

Furazolidone-200 g, Inorganic nutritive carrier-Q.S.

4. Metabolic activator:

Lecithin extract treated with co enzyme.

5. Toxin binder:

Selected silicates, surfactants, organic acids and salts of organic acids.

6. Maduramicin:

Ionophore (polyether antibiotic) coccidiostat.

7. Herbal performance enhancer @ $250 \mathrm{~g}$ per tonne of feed.

8. Vitamin $\mathrm{B}_{12}$ :

Each $\mathrm{kg}$ contains: Vitamin $\mathrm{B}_{12}-100 \mathrm{mg}$

9. Vitamin and mineral supplement:

Each 2 kg contains:

Vitamin A-50 lakh IU, Vitamin B2-2 g,

Vitamin B6-400 mg, Vitamin B12-5600 mcg, Vitamin

E-800 IU, Iron-7.5 g, Vitamin D3-6.25 lakh IU,

Choline chloride-10 g, Copper-2 g, Iodine-1 g,

Zinc-15 g, Manganese-27.5 g, Calcium-27.25\%,

Phosphorus- $7.45 \%$, Calcium pantothenate- $4 \mathrm{~g}$. 
Whereas, in $\mathrm{T}_{5}$ group, probiotic was given at the rate of $50 \mathrm{~g} /$ tonne of feed and prebiotic was given at the rate of $250 \mathrm{~g} /$ tonne of feed during starter phase and finisher phase i.e. half of the dose than $\mathrm{T}_{4}$ treatment. Each gram of probiotic contains $6 \times 10^{9}$ colony forming units of Lactobacillus acidophilus, Lactobacillus casei, Pediococcus acidilactici, Bacillus subtilis and Saccharomyces boulardii. Whereas, prebiotic contains Mannan Oligo-Saccharide in which Mannan 12-14\% and Glucan $13-16 \%$ were included. The broiler starter (0-28 days) and broiler finisher (29-42 days) feeds for different treatments were prepared as per the guidelines of BIS (1992). Return Over Feed Cost (ROFC) is calculated by subtracting the feed cost during the rearing period from the income from the sold bird on live weight basis. Whereas European Performance Efficiency Index (EPEI) (European Performance Efficiency Index), as described by [9], was calculated by following formula.

$$
\mathrm{EPEI}=\frac{\text { Ave. body weight }(\mathrm{g}) \times \text { Livability }(\%)}{\text { Age of flock }(\text { days }) \times \mathrm{FCR}} \div 10
$$

\section{Statistical analysis}

The data on various traits were analyzed using completely randomized design as per Snedecor and Cochran (1995) [10].

\section{Results and Discussion}

The carcass traits like dressed weight, dressing $\%$, liver weight, heart weight, gizzard weight, giblet weight, giblet $\%$, abdominal fat weight, abdominal fat $\%$, intestinal length and kidney weight of the different groups offered feed additives either singly or in combination in relation to control is presented in Table-3.

\section{Dressed weight}

The average body weight gain for different treatment group and for weekly interval as well as for starter and finisher phase is given in Table-4. The highest dressed weight was observed in synbiotic half level group $\left(\mathrm{T}_{5}\right)$, which was followed by $\mathrm{T}_{2}, \mathrm{~T}_{3}, \mathrm{~T}_{4}$ and $\mathrm{T}_{1}$ groups. Dressed weight was highest in $\mathrm{T}_{5}$ though it had the lowest pre-slaughter weight. The dressed weight differences were non-significant amongst all treatment groups. Present findings were in accordance with [11-14].

\section{Dressing yield (\%)}

The highest dressing per cent was observed in synbiotic half level group $\left(T_{5}\right)$ which was followed by $\mathrm{T}_{3}, \mathrm{~T}_{2}, \mathrm{~T}_{4}$ and $\mathrm{T}_{1}$ group and all treatment groups dressing percentages were significantly $(p<0.05)$ higher than control group but with non-significant difference between supplemental groups. Present findings differed from $[11-13,15,16]$ as they all observed non-significant differences between supplemental groups and

Table-3: Carcass characteristics of commercial broilers fed with or without probiotic, prebiotic or synbiotic supplemented feed.

\begin{tabular}{|c|c|c|c|c|c|c|}
\hline \multirow[t]{2}{*}{ Carcass trait } & \multicolumn{5}{|c|}{ Treatments } & \multirow{2}{*}{$\begin{array}{c}\text { CD } \\
\text { value }\end{array}$} \\
\hline & $\mathbf{T}_{1}$ & $\mathbf{T}_{2}$ & $\mathbf{T}_{3}$ & $\mathbf{T}_{\mathbf{4}}$ & $\mathbf{T}_{5}$ & \\
\hline Pre-slaughter weight (g) & $1965.00 \pm 46.94$ & $1950.00 \pm 20.41$ & $1932.50 \pm 34.97$ & $1945.00 \pm 35.70$ & $1925.00 \pm 14.43$ & NS \\
\hline Dressed weight (g) & $1247.75 \pm 31.65$ & $1312.75 \pm 15.19$ & $1309.50 \pm 30.80$ & $1305.00 \pm 42.28$ & $1326.50 \pm 10.74$ & NS \\
\hline Dressing \% & $63.51^{\mathrm{a}} \pm 0.99$ & $67.35^{\mathrm{b}} \pm 1.06$ & $67.76^{\mathrm{b}} \pm 1.01$ & $67.06^{\mathrm{b}} \pm 1.24$ & $68.92^{b} \pm 0.64$ & 3.04 \\
\hline Liver weight (g) & $40.75 \pm 2.21$ & $42.13 \pm 1.08$ & $40.50 \pm 1.32$ & $45.25 \pm 1.70$ & $46.00 \pm 2.16$ & NS \\
\hline Heart weight $(\mathrm{g})$ & $8.75 \pm 0.52$ & $9.50 \pm 0.64$ & $7.75 \pm 0.85$ & $8.75 \pm 0.47$ & $7.88 \pm 1.08$ & NS \\
\hline Gizzard weight (g) & $34.25 \pm 1.65$ & $36.38 \pm 3.41$ & $37.25 \pm 0.62$ & $32.75 \pm 3.68$ & $34.38 \pm 2.62$ & NS \\
\hline Giblet weight $(\mathrm{g})$ & $83.75 \pm 2.77$ & $88.00 \pm 4.14$ & $85.50 \pm 0.95$ & $86.75 \pm 4.49$ & $88.25 \pm 3.78$ & NS \\
\hline Giblet \% & $6.72 \pm 0.25$ & $6.70 \pm 0.30$ & $6.54 \pm 0.11$ & $6.64 \pm 0.21$ & $6.65 \pm 0.25$ & NS \\
\hline Abdominal fat weight $(\mathrm{g})$ & $38.63^{b} \pm 1.65$ & $32.50^{\mathrm{a}} \pm 1.50$ & $36.00^{\mathrm{ab}} \pm 1.22$ & $31.75^{\mathrm{a}} \pm 1.18$ & $33.75^{\mathrm{a}} \pm 1.75$ & 4.45 \\
\hline Abdominal fat \% & $3.10^{\mathrm{b}} \pm 0.15$ & $2.47^{\mathrm{a}} \pm 0.09$ & $2.76^{\mathrm{ab}} \pm 0.13$ & $2.45^{\mathrm{a}} \pm 0.16$ & $2.54^{\mathrm{a}} \pm 0.11$ & 0.41 \\
\hline Intestinal length (inches) & $79.50 \pm 2.59$ & $82.25 \pm 1.93$ & $78.00 \pm 3.34$ & $80.25 \pm 0.85$ & $81.00 \pm 2.04$ & NS \\
\hline Kidney weight $(\mathrm{g})$ & $15.75 \pm 1.31$ & $14.00 \pm 2.04$ & $15.00 \pm 1.87$ & $14.25 \pm 1.31$ & $16.50 \pm 1.89$ & NS \\
\hline
\end{tabular}

*Means within row with different superscript differ significantly $(p<0.05)$, NS=Non-significant

Table-4: Average body weight gain ( $\mathrm{g}$ ) of commercial broilers under different treatments for weekly interval up to 6 weeks age.

\begin{tabular}{|c|c|c|c|c|c|c|}
\hline \multirow[t]{2}{*}{ Weeks } & \multicolumn{5}{|c|}{ Treatments } & \multirow{2}{*}{$\begin{array}{c}\text { CD } \\
\text { value }\end{array}$} \\
\hline & $\mathbf{T}_{1}$ & $\mathbf{T}_{2}$ & $\mathbf{T}_{3}$ & $\mathbf{T}_{4}$ & $\mathbf{T}_{5}$ & \\
\hline $0-1$ & $81.53^{\mathrm{a}} \pm 1.96$ & $110.10^{b} \pm 3.62$ & $107.76^{b} \pm 1.89$ & $103.74^{b} \pm 3.06$ & $104.45^{\mathrm{b}} \pm 4.45$ & 9.51 \\
\hline $1-2$ & $133.98 \pm 4.62$ & $152.73 \pm 3.90$ & $155.94 \pm 4.86$ & $150.91 \pm 5.00$ & $155.88 \pm 8.19$ & NS \\
\hline $2-3$ & $296.89 \pm 8.15$ & $296.63 \pm 9.44$ & $312.30 \pm 9.60$ & $313.40 \pm 13.05$ & $306.95 \pm 9.02$ & NS \\
\hline $3-4$ & $438.35 \pm 10.40$ & $455.50 \pm 6.88$ & $461.03 \pm 10.84$ & $446.64 \pm 12.24$ & $488.32 \pm 39.12$ & NS \\
\hline $4-5$ & $473.18 \pm 21.74$ & $477.45 \pm 16.47$ & $481.33 \pm 9.90$ & $515.35 \pm 7.23$ & $488.89 \pm 8.68$ & NS \\
\hline $5-6$ & $489.23 \pm 5.21$ & $517.30 \pm 28.45$ & $535.58 \pm 4.00$ & $499.40 \pm 21.42$ & $499.00 \pm 17.37$ & NS \\
\hline $0-4$ & $950.74 \pm 12.33$ & $1014.94 \pm 17.39$ & $1037.03 \pm 12.28$ & $1014.69 \pm 30.19$ & $1055.59 \pm 39.98$ & NS \\
\hline $4-6$ & $962.40 \pm 25.23$ & $994.75 \pm 23.83$ & $1016.90 \pm 7.15$ & $1014.75 \pm 24.45$ & $987.89 \pm 24.60$ & NS \\
\hline $0-6$ & $1913.14 \pm 31.87$ & $2009.69 \pm 36.74$ & $2053.93 \pm 14.25$ & $2029.44 \pm 28.11$ & $2043.49 \pm 58.34$ & NS \\
\hline
\end{tabular}

*Means within row with different superscript differ significantly $(p<0.05)$ 
control groups. The average dressing percentage for different treatment groups is shown in Figure-1.

\section{Liver weight}

The highest liver weight was observed in synbiotic half level group $\left(\mathrm{T}_{5}\right)$, which was followed by $\mathrm{T}_{4}, \mathrm{~T}_{2}, \mathrm{~T}_{1}$ and $\mathrm{T}_{3}$ group. There were a non-significant difference between all the treatment groups for liver weight $[13,14,17,18]$ found similar findings.

\section{Heart weight}

The heart weight with the highest value observed in the probiotic group $\left(T_{2}\right)$ which was followed by $T_{1}$, $\mathrm{T}_{4}, \mathrm{~T}_{5}$ and $\mathrm{T}_{3}$ group. There was non-significant difference between all the treatment groups $[13,14,17]$ found similar findings to this study.

\section{Gizzard weight}

The highest gizzard weight was observed in the prebiotic group $\left(\mathrm{T}_{3}\right)$ which was followed by $\mathrm{T}_{2}$, $\mathrm{T}_{5}, \mathrm{~T}_{1}$ and $\mathrm{T}_{4}$ group. There was non-significant difference between all the treatment groups $[13,17,18]$ also reported similar findings. The average weight of the organs has been shown in Figure-2.

\section{Giblet weight}

The highest giblet weight was observed in synbiotic half level group $\left(\mathrm{T}_{5}\right)$ which was followed by $\mathrm{T}_{2}$, $\mathrm{T}_{4}, \mathrm{~T}_{3}$ and $\mathrm{T}_{1}$ group. There were non-significant differences between all the treatment groups.

\section{Abdominal fat weight and \%}

The control group $\left(\mathrm{T}_{1}\right)$ birds were having highest abdominal fat $\%$ which was significantly $(\mathrm{p}<0.05)$ higher than $\mathrm{T}_{5}, \mathrm{~T}_{2}$ and $\mathrm{T}_{4}$ group though there was a non-significant difference between control and prebiotic supplemented group $\left(\mathrm{T}_{3}\right)$. The lowest abdominal fat $\%$ was observed in the synbiotic group $\left(\mathrm{T}_{4}\right)$. The highest abdominal fat $\%$ in the control group was followed by $\mathrm{T}_{3}, \mathrm{~T}_{5}, \mathrm{~T}_{2}$ and $\mathrm{T}_{4}$ groups. Present study was in accordance with results of $[11,14,19]$. Present study differed from results of $[12,15,16,20]$.

\section{Intestinal length}

The highest intestinal length was found in the probiotic supplemented group $\left(\mathrm{T}_{2}\right)$ which was followed by $\mathrm{T}_{5}, \mathrm{~T}_{4}, \mathrm{~T}_{1}$ and $\mathrm{T}_{3}$. The intestinal length was

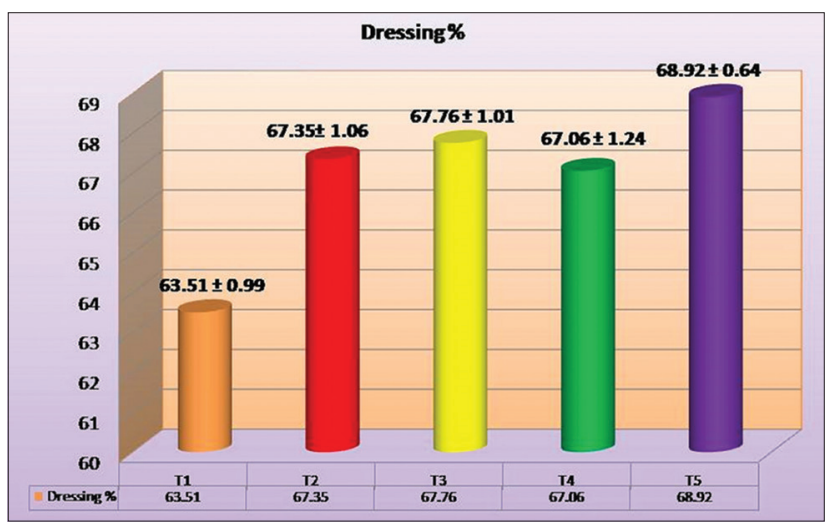

Figure-1: The average dressing percentages of birds under different treatments. not differing among each other though numerical differences were there. Present study was in accordance with findings of [16] but values for intestinal length were lower than present findings.

\section{Kidney weight}

The highest kidney weight was noticed in the synbiotic half level group $\left(T_{5}\right)$ which was followed by $\mathrm{T}_{1}, \mathrm{~T}_{3}, \mathrm{~T}_{4}$ and $\mathrm{T}_{2}$ group and there were non-significant differences amongst each other. Present study was in accordance with the results of [14] who observed lower kidney weight than the present study.

Amongst all carcass traits, dressing percentage, abdominal fat weight and abdominal fat percentage (as a percentage of dressed weight) were recorded significant $(\mathrm{p}<0.05)$ difference amongst different treatment groups. Synbiotic half level supplemented $\left(\mathrm{T}_{5}\right)$ was dominating for most of the traits. Higher dressed weight, higher dressing percentage, higher liver weight, higher giblet weight and higher kidney weight was observed in synbiotic half level supplemented group $\left(\mathrm{T}_{5}\right)$ than all other treatments. Synbiotic group $\left(\mathrm{T}_{4}\right)$ was having lower abdominal fat weight and lower abdominal fat percentage (as a percentage of dressed weight) among all treatment. Prebiotic group $\left(\mathrm{T}_{3}\right)$ had higher gizzard weight than other groups. Whereas, a probiotic group $\left(\mathrm{T}_{2}\right)$ had higher heart weight and longer intestinal length amongst all supplemental groups. Giblet percentage (as a percentage of dressed weight) was higher in the control group.

\section{ROFC}

Average ROFC in terms of (Rs./bird), (\%/bird), income from selling and feed cost of broilers under different treatment groups has been shown in Table-5 and Figure-3. Cost of feed per $\mathrm{kg}$ for different treatment groups is shown in Table-6. ROFC in terms of \% per bird was indicating the per cent of profit in treatment as compared to the control group. Average daily feed consumption ( $\mathrm{g} / \mathrm{b}$ ird/day) is given in Table-7. The income from selling of the birds was significantly $(p<0.05)$ higher in all treatment groups than the control group but there was a non-significant difference between supplemented groups. Feed cost during whole experimental

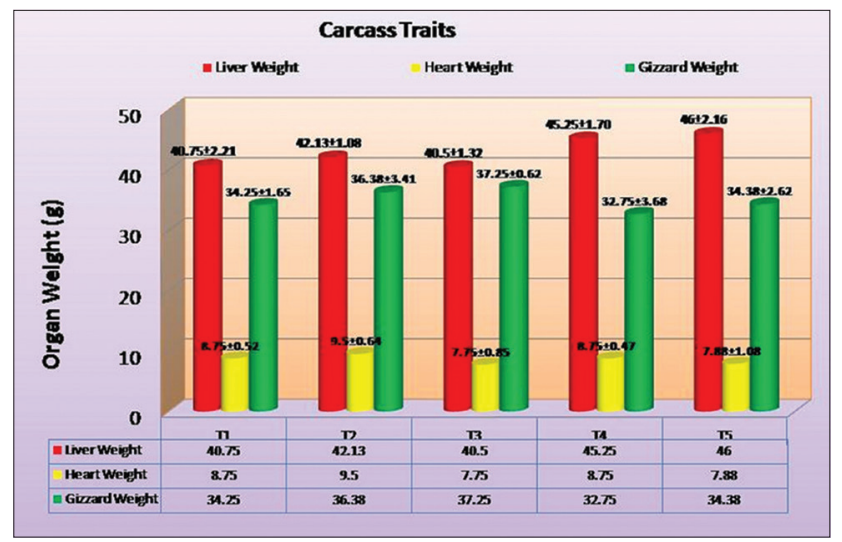

Figure-2: The average weight of organs included in giblet under different treatment groups. 
Table-5: The ROFC (Rs/bird) and (\%/bird) realized under different feed supplement groups.

\begin{tabular}{|c|c|c|c|c|c|c|}
\hline \multirow[t]{2}{*}{ Particulars } & \multicolumn{5}{|c|}{ Treatment } & \multirow{2}{*}{$\begin{array}{c}\text { CD } \\
\text { value }\end{array}$} \\
\hline & $T_{1}$ & $\mathbf{T}_{2}$ & $\mathbf{T}_{3}$ & $\mathbf{T}_{4}$ & $T_{5}$ & \\
\hline Income from bird sold (Rs./bird) & $141.32^{\mathrm{a}} \pm 2.25$ & $148.28^{\mathrm{b}} \pm 2.62$ & $151.44^{b} \pm 1.01$ & $149.67^{b} \pm 2.03$ & $150.75^{\mathrm{b}} \pm 1.31$ & 5.85 \\
\hline Feed cost (Rs./bird) & $85.50^{\mathrm{b}} \pm 1.34$ & $83.63^{\mathrm{b}} \pm 2.38$ & $84.32^{b} \pm 0.60$ & $78.85^{\mathrm{a}} \pm 1.14$ & $78.47^{a} \pm 1.18$ & 4.37 \\
\hline ROFC (Rs./bird) & $55.82^{\mathrm{a}} \pm 1.13$ & $64.64^{b} \pm 0.72$ & $67.12^{\mathrm{bc}} \pm 1.57$ & $70.82^{\mathrm{cd}} \pm 2.38$ & $72.28^{d} \pm 1.43$ & 4.66 \\
\hline ROFC (Rs./kg live weight) & 28.43 & 31.38 & 31.91 & 34.06 & 34.52 & - \\
\hline ROFC (\%/bird) & 00.00 & 15.80 & 20.24 & 26.87 & 29.48 & - \\
\hline
\end{tabular}

ROFC $=$ Return over feed cost, *Means within row with different superscript differ significantly $(p<0.05)$

Table-6: Cost of feed of control and supplemented with probiotic, prebiotic and synbiotic.

\begin{tabular}{llllll}
\hline Type of feed & $T_{1}$ & $T_{2}$ & $T_{3}$ & $T_{4}$ & $T_{5}$ \\
\hline
\end{tabular}

\begin{tabular}{llllll}
\hline Broiler starter (Rs./kg) & 22.32 & 22.49 & 22.39 & 22.56 & 22.44
\end{tabular} Broiler finisher (Rs./kg) $22.02 \quad 22.1922 .09 \quad 22.26 \quad 22.14$

period was significantly $(\mathrm{p}<0.05)$ lower in synbiotic supplemented groups $\left(\mathrm{T}_{4}\right.$ and $\left.\mathrm{T}_{5}\right)$ than other groups. ROFC of the control group found significantly $(\mathrm{p}<0.05)$ lower than all treatment groups. Non-significant difference was found between $T_{2}$ and $T_{3}, T_{3}$ and $T_{4}$ and $T_{4}$ and $\mathrm{T}_{5}$. In terms of percentage, highest ROFC was in $\mathrm{T}_{5}(29.48 \%)$ than $\mathrm{T}_{4}(26.87 \%)$ followed by $\mathrm{T}_{3}(20.24 \%)$ and $\mathrm{T}_{2}(15.80 \%)$ as compared to control $\left(\mathrm{T}_{1}\right)$ suggesting incorporation of synbiotic yields more return and we can afford its $50 \%$ level for better economy. The present study was in accordance with $[11,21,22]$ though they observed lower values of profit as compared to present findings, but the trend was same.

EPEI

The EPEI for performance of the broilers is given in Table-8 and Figure-4. The EPEI value was higher in $\mathrm{T}_{4}$ (285.76) which was followed by $\mathrm{T}_{3}(271.34)$, $\mathrm{T}_{2}$ (263.24), $\mathrm{T}_{5}(261.20)$ and $\mathrm{T}_{1}$ (231.78). All supplemented groups were having significantly $(p<0.05)$ higher EPEI value than the control. There was a non-significant difference between $\mathrm{T}_{2}, \mathrm{~T}_{3}, \mathrm{~T}_{5}$ and $\mathrm{T}_{2}$, $\mathrm{T}_{3}, \mathrm{~T}_{4}$. The higher EPEI value means higher average body weight; good livability and higher feed efficiency in stipulated number of days thus give overall economics of the birds considering various important traits. Hence, $\mathrm{T}_{4}$ group (synbiotic) found more economical than other group when EPEI considered.

\section{Conclusion}

Dressing percentage was highest in synbiotic $\left(50 \%\right.$ level) group $\left(\mathrm{T}_{5}\right)$ over other supplemented groups and differed significantly with control in spite of having lowest pre-slaughter weight. The ROFC (Rs.) was significantly $(p<0.05)$ higher in the synbiotic group $\left(\mathrm{T}_{4}\right.$ and $\left.\mathrm{T}_{5}\right)$ than other groups. Also, ROFC in terms of per cent per bird was highest in synbiotic $\left(50 \%\right.$ level) group $\left(\mathrm{T}_{5}\right)$ than all other groups. EPEI was highest in symbiotic $(100 \%)$ group $\left(\mathrm{T}_{4}\right)$ over other group which means higher average body weight; good livability and higher feed efficiency in stipulated number of days by the group.

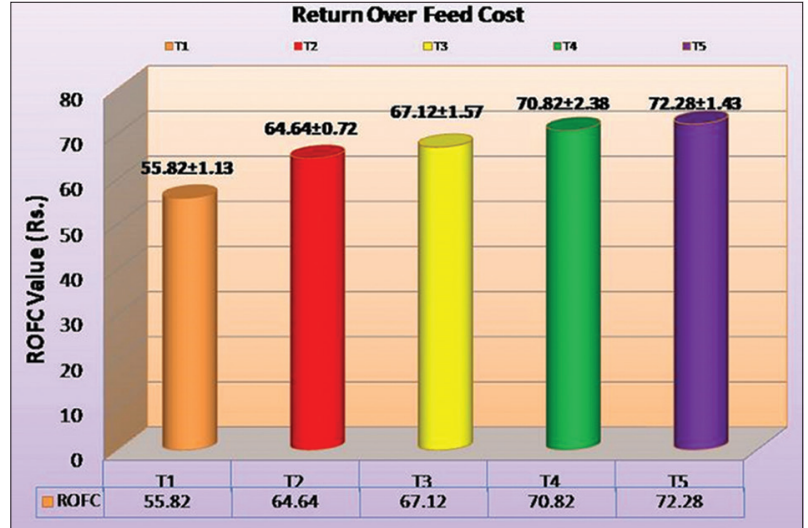

Figure-3: The Return Over Feed Cost (ROFC) for various treatment groups in commercial broilers.

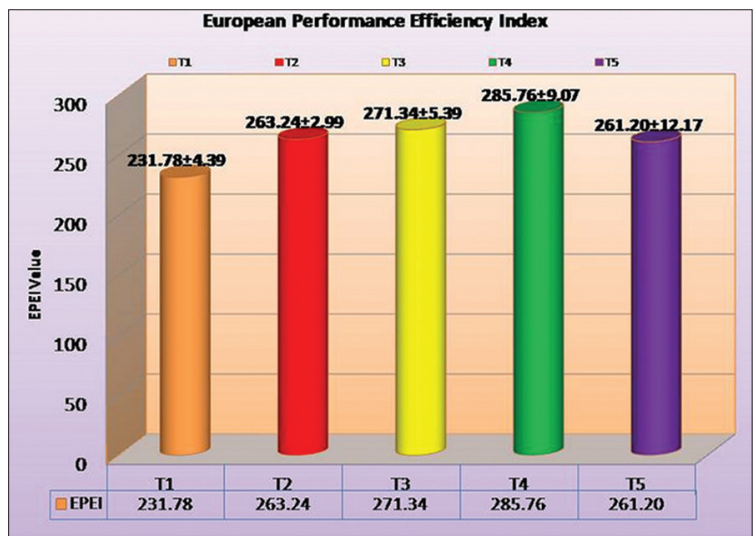

Figure-4: European Performance Efficiency Index (EPEI) for various treatment groups in commercial broilers.

Overall it can be concluded that the diet supplemented with synbiotic ( $100 \%$ level) was most efficient in terms of EPEI and synbiotic (50\% level) in terms of ROFC. Hence, As feed supplement, synbiotic has a beneficial effect over probiotic and prebiotic when used alone.

\section{Authors' Contributions}

RSJ designed the experiment. MAS, FPS and RSJ carried out the research. MAS, ABP and RKM drafted and revised the manuscript. ABP, NJB, RSJ and FPS recorded and analysed the data All authors read and approved the final manuscript.

\section{Acknowledgments}

The authors are thankful to the Dean, College of Veterinary Science and Animal Husbandry, Anand, 
Table-7: Average daily feed consumption ( $\mathrm{g} / \mathrm{bird} / \mathrm{day}$ ) of commercial broilers for different treatments during different time intervals.

\begin{tabular}{|c|c|c|c|c|c|c|}
\hline \multirow[t]{2}{*}{ Weeks } & \multicolumn{5}{|c|}{ Treatments } & \multirow{2}{*}{$\begin{array}{c}C D \\
\text { value }\end{array}$} \\
\hline & $T_{1}$ & $\mathbf{T}_{2}$ & $\mathbf{T}_{3}$ & $\mathbf{T}_{4}$ & $T_{5}$ & \\
\hline $0-1$ & $20.13 \pm 0.14$ & $19.31 \pm 0.18$ & $19.38 \pm 0.20$ & $19.50 \pm 0.35$ & $19.16 \pm 0.56$ & NS \\
\hline $1-2$ & $41.58^{b} \pm 0.50$ & $36.83^{\mathrm{a}} \pm 0.12$ & $36.64^{\mathrm{a}} \pm 0.17$ & $37.08^{\mathrm{a}} \pm 0.30$ & $36.86^{\mathrm{a}} \pm 0.15$ & 0.86 \\
\hline $2-3$ & $67.84 \pm 0.84$ & $69.92 \pm 1.03$ & $69.60 \pm 0.43$ & $69.37 \pm 0.59$ & $68.59 \pm 0.68$ & NS \\
\hline $3-4$ & $133.26^{c} \pm 1.26$ & $126.70^{`} \pm 4.78$ & $129.34^{c} \pm 2.47$ & $115.48^{\mathrm{b}} \pm 1.57$ & $107.13^{a} \pm 2.04$ & 8.23 \\
\hline $4-5$ & $152.77 \pm 4.34$ & $137.70 \pm 6.25$ & $136.33 \pm 2.00$ & $137.79 \pm 4.10$ & $136.75 \pm 2.31$ & NS \\
\hline $5-6$ & $135.54^{\mathrm{ab}} \pm 3.95$ & $144.56^{\mathrm{bc}} \pm 6.50$ & $150.55^{`} \pm 0.98$ & $123.58^{\mathrm{a}} \pm 5.34$ & $134.73^{\mathrm{ab}} \pm 3.66$ & 13.54 \\
\hline $0-4$ & $65.70^{d} \pm 0.51$ & $63.19^{c} \pm 1.09$ & $63.74^{\mathrm{cd}} \pm 0.67$ & $60.36^{b} \pm 0.52$ & $57.93^{a} \pm 0.58$ & 2.14 \\
\hline $4-6$ & $144.16 \pm 3.95$ & $141.13 \pm 5.58$ & $143.44 \pm 1.03$ & $130.68 \pm 2.97$ & $135.74 \pm 2.83$ & NS \\
\hline $0-6$ & $91.85^{b} \pm 1.44$ & $89.17^{b} \pm 2.54$ & $90.31^{\mathrm{b}} \pm 0.64$ & $83.80^{\mathrm{a}} \pm 1.21$ & $83.87^{a} \pm 1.26$ & 4.67 \\
\hline
\end{tabular}

*Means within row with different superscript differ significantly $(p<0.05)$

Table-8: The EPEI of broilers fed with Probiotic, Prebiotic and their combination under different treatment.

\begin{tabular}{lcccccc}
\hline Particulars & \multicolumn{5}{c}{ Treatment } & CD \\
\cline { 2 - 7 } & $\mathbf{T}_{\mathbf{1}}$ & $\mathbf{T}_{\mathbf{2}}$ & $\mathbf{T}_{\mathbf{3}}$ & $\mathbf{T}_{\mathbf{4}}$ & $\mathbf{T}_{\mathbf{5}}$ & value \\
\hline EPEI & $231.78^{\mathrm{a}} \pm 4.39$ & $263.24^{\mathrm{bc}} \pm 2.99$ & $271.34^{\mathrm{bc}} \pm 5.39$ & $285.76^{\mathrm{c}} \pm 9.07$ & $261.20^{\mathrm{b}} \pm 12.17$ & 22.87 \\
\hline
\end{tabular}

$E P E I=$ European performance efficiency index, $*$ Means within row with different superscript differ significantly $(p<0.05)$

Gujarat for providing necessary funds and facilities for this research.

\section{Competeing Interests} interests.

The authors declare that they have no competing

\section{References}

1. Prabhakaran, R. (2012) Overview of poultry production in India vis-a-vis global scenario. In the Proceeding of XXIX Annual Conference and National Symposium of Indian Poultry Science Association (IPSACON-2012) on Commercial and Rural Poultry Production: Novel Concepts and Strategies to Meet Growing Demand and Changing Consumers Needs. $5^{\text {th }}-7^{\text {th }}$ December at Hyderabad. p3-11.

2. Kokje, R.P. (1999) Effect of feeding probiotics on growth performance in commercial broilers. M. V. Sc. Thesis Submitted to Gujarat Agricultural University, Anand.

3. Hinton, M., Kaukas, A. and Linton, A.H. (1986) The ecology of drug resistance in enteric lactobacilli on the performance of broilers. J. Appl. Bacteriol., 15: 77-92. (c. f. Sen, S. Ingale, S.L., Kim, Y.W., Kim, J.S., Kim, K.H., Lohakare, J.D., Kim, E.K., Kim, H.S., Ryu, M.H., Kwon, I.K. and Chae, B.J. (2012). Effect of dietary supplementation of probiotics on performance, caecal morphology and small intestinal morphology of broiler chickens. Anim. Nutr. Feed Technol, 12(1): 1-12).

4. Barton, M.D. (2000) Antibiotic use in animal feed and its impact on human health. Nutr. Res. Rev., 13: 279-299.

5. FAO. (2001) Evaluation of health and nutritional properties of powder milk and live lactic acid bacteria. Food and Agriculture Organization of the United Nations and World Health Organization Expert Consultation Report Cordoba/ Argentina. p1-34.

6. Sekhon, B.S. and Jairath, S. (2010) Prebiotics, probiotics and synbiotics: An overview. J. Pharm. Educ. Res., 1(2): 13-36.

7. Ivanovic, S., Baltic, M., Popov-Raljic, J., Pisinov, B., Maslic-Strizak, D., Stojanovic, Z., and Pavlovic, I. (2012) The effect of different probiotics on broiler meat quality. Afr. J. Microbiol. Res., 6(5): 937-943.

8. Singh, R.P. (2012) Present status and prospects of egg and poultry processing in india. XXIX annual conference and national symposium of Indian poultry science association
(IPSACON-2012) on commercial and rural poultry production: Novel concepts and strategies to meet growing demand and changing consumers needs. $5^{\text {th }}-7^{\text {th }}$ December at Hyderabad. p111-115.

9. Sharma, N. (2007) Effect of supplementation of enzymes on growth performance in commercial broilers. A Thesis Submitted to Anand Agricultural University. p49.

10. Snedecor, G.W. and Cochran, W.G. (1995) Statistical Methods. $8^{\text {th }}$ ed. The Iowa State University Press, Ames, Iowa, USA.

11. Anjum, M.I. Khan, A.G. Azim, A. and Afzal, M. (2005) Effect of dietary supplementation of multi-strain probiotic on broiler growth performance. Pak. Vet. J., 25(1): 25-29.

12. Bozkurt, M., Kucukayilmaz, K., Catli, A.U. and Cinar, M. (2009) The effect of single or combined dietary supplementation of prebiotics, organic acid and probiotics on performance and slaughter characteristics of broilers. S. Afr. J. Anim. Sci., 39(3): 197-205.

13. Abdel-Raheem, M. and Abd-Allah, M.S. (2011) The effect of single or combined dietary supplementation of mannan oligosacharide and probiotics on performance and slaughter characteristics of broilers. Int. J. Poult. Sci., 10(11): 854-862.

14. Sojoudi, M.R., Dadashbeiki, M. and Bouyeh, M. (2012) Effect of different levels of prebiotics TechnoMos on carcass characteristics of broiler chickens. J. Basic Appl. Sci. Res., 2(7): 6778-6794.

15. Mohamed, M.A., Hassan, H.M.A. and El-Barkouky, E.M.A. (2008) Effect of mannan oligosaccharide on performance and carcass characteristics of broiler chicks. J. Agric. Soc. Sci., 4(1): 13-17.

16. Toghyani, M., Toghyani, M. and Tabeidian, S.A. (2011) Effect of probiotic and prebiotic as antibiotic growth promoter substitutions on productive and carcass traits of broiler chicks. Int. Conf. Food Eng. Biotechnol., 9: 82-86.

17. Awad, W.A., Ghareeb, K., Abdel-Raheem, S. and Bohm, J. (2009) Effects of dietary inclusion of probiotic and synbiotic on growth performance, organ weights and intestinal histomorphology of broiler chickens. Poult. Sci., 88: 49-55.

18. Dizaji, B.R. Hejazi, S. and Zakeri, A. (2012) Effects of dietary supplementations of prebiotics, probiotics, synbiotics and acidifiers on growth performance and organs weights of broiler chicken. Eur. J. Exp. Biol., 2(6): 2125-2129.

19. Swain, B.K., Naik, P.K., Chakurkar, E.B. and Singh, N.P. (2012) Effect of combined supplementation of probiotic 
and yeast on growth, carcass characteristics and economics of production in broiler chickens. Anim. Nutr. Feed Technol, 12: 103-110.

20. Ashayerizadeh, A., Dabiri, N., Mirzadeh, K. and Ghorbani, M.R. (2011) Effects of dietary inclusion of several biological feed additives on growth response of broiler chickens. J. Cell Anim. Biol., 5(4): 61-65.
21. Ramlah, A.H. and Tan, C.K. (1995) Effects of probiotic supplementation on broiler performance. Perlanika J. Trop. Agric. Sci., 18(2): 109-112.

22. Munj, C.P., Ranade, A.S., Desai, D.N., Patil, M.B., Avari, P.E., Patil, U.M. and Metakari, D.V. (2010) Synergistic effects of feed additives on performance of broilers. Indian J. Poult. Sci., 45(3): 292-296.

$* * * * * * * *$ 